\title{
U.S. Working Class History and Contemporary Labor Movement Symposium
}

\author{
Irwin M. Marcus \\ Indiana University of Pennsylvania
}

The mid-1980s confront historians of the U.S. working-class and labor activists with new challenges and opportunities. The fiftieth anniversary of the founding of the CIO brings to mind a special era in which activism reached a high point but failed to produce a fundamental societal transformation. The results of the decade 1935-45 established the basic foundation for both the writing of labor history and the practice of labor-management relations for the next three decades. Many labor historians applauded the mass organizing drives and the expanded and broadened union membership which it produced. A professional labor leadership and a growing labor bureaucracy emerged to negotiate and enforce massive collective bargaining agreements which produced wage improvements, fringe benefit gains, and protections on the shop floor. In the last decade the global economy has eroded the size and power of the industrial labor force with employment shifts to the service and high-tech sectors and a geographical shift from the frostbelt to the sunbelt and overseas. This economic transformation placed pressure on corporate profits in the manufacturing sector and executives responded by demanding concessions. Simultaneously, some working-class historians responded to the decline of the CIO era by examining missed alternatives of the 1930s and seeking grassroots mobilization as a valuable building block for a renewed labor movement in the late 1980 s.

Against this background of shifts in worker and union experiences and historical interpretation, Indiana University of Pennsylvania hosted a symposium, "U.S. Working Class History and the Contemporary Labor Movement," October 23-25, 1985. The program featured a group of diverse speakers, mainly academics plus a few labor activists. The academics represented several disciplines in addition to history, including economics, sociology and literature. Videotapes, a play by the N.Y. Street Theatre Caravan, and social events supplemented the more traditional aspects of the program.

Melvyn Dubofsky (SUNY, Binghamton), the first keynoter, offered the primary framework for the symposium by exploring the themes of fragmentation and solidarity in the history of workers in industrial America. He mentioned the fissures created by race, gender, and ethnicity in undermining working class unity. William Harris (Paine College) corroborated this interpretation with

International Labor and Working Class History

No. 29 , Spring 1986 , pp. 97-101

(C) 1986 by the Board of Trustees of the University of Illinois 
historical examples and family experiences. His father, the possessor of substantial mechanical skills, remained a helper although he trained white workers who rose to higher positions. Celia Eckhardt (author of Fanny Wright: Rebel in America) and Alice Kessler-Harris (Hofstra University) provided examples of gender divisions fragmenting working-class unity. Eckhardt, in her discussion of Fanny Wright's involvement in New York working-class politics of the 1830 s, noted the magnetism of her oratorical style and message to throngs of working men, contrasted to her exclusion from their bars. Alice Kessler-Harris described other forms of class fragmentation which resulted from job descriptions based exclusively on the interest of males in higher wages and promotions. The labor movement often accepted this viewpoint as the class norm although many women saw the home and family as a worthwhile sphere and sought a balance which would not require a sacrifice of workplace or nonworkplace activities. At times the mixture of fragmentation and solidarity became complex as Professor Dubofsky noted. In the 1919 strike wave, examples of unprecedented ethnic solidarity coexisted with racial fragmentation.

Symposium presenters devoted more attention to examples of solidarity than to fragmentation. Melvyn Dubofsky described the widespread support which strikers in the Railway Strike of 1877 received from workers, the unemployed, and community residents. Boycotts and sympathy strikes became very popular in the 1880s and 1890 s as workers and their supporters boycotted hats, cigars, and newspapers and rallied behind the Homestead Strike and Pullman Boycott. In the 1930s and UAW sit-down strikers in Flint won support from the Women's Emergency Brigade and the rubber workers and other industrial workers in the vicinity.

David Gordon (New School for Social Research), the second keynoter, used locale as the theme of his presentation, taking account of both the workplace and the surrounding communities as vital terrains in the outcome of labor conflicts. Using the 1880 s and 1890 s as an initial illustration, he described how workers took their demands from the workplace into the community and aroused neighborhood backing for strikes and political activity. Their success inspired an employer counterattack. The employers retaliated against this concentration of power by relocating plants in areas distant from workingclass and ethnic neighborhoods. The new locations gave employers the upper hand, and they used this increased power to press workers for increased production. In the auto industry the speed-up became common until auto workers counterattacked with unionization and sit-down strikes. Industrial unionism provided factory-wide solidarity, but workers lacked connections with employees in other industries and the non-union sector. Sean Wilentz (Princeton University) used urban history and a geographical perspective to frame his talk on New York in the 1830s. He presented a walking tour of lower Manhattan based on the route of an artisans' parade. The marchers used City Hall as their assembly point to claim the building for "the people" and to begin parading 
with their backs to Wall Street. Divisions became more common with the rise of "metropolitan industrialism." Master and artisans no longer marched together as they had done to commemorate the opening of the Erie Canal in 1825. The gap in wealth and power between the classes increased and artisans responded to this situation with demands for equal rights.

Cultural factors received attention from several speakers who sought new frames of reference. Celia Eckhardt characterized Frances Wright as relatively conservative in economic outlook but a cultural radical. Wright condemned slavery, religion, and marriage and sought equality, especially for women, with education serving as a primary instrument for social change. Surprisingly, the leader of the Women's Christian Temperance Union in the 1880s, Frances Willard, shared some of her perspectives. Both reformers emphasized equal rights and viewed the labor movement as an important means of promoting the interests of workers and women. Mari Jo Buhle (Brown University) presented Willard as a crusader for women's suffrage and an advocate of equal pay for equal work. Aided by the Knights of Labor and other sympathetic labor organizations women workers made some gains, but male dominance and standards remained. Alice Kessler-Harris used the case of the EEOC v. Sears Roebuck and Company to illustrate an ongoing cultural facet of working-class relations. The suit charges the company with sexual discrimination on the basis of the low percentage of women in commission sales positions. Sears responded to this contention by asserting that most women refused to sacrifice home and family interests to the demands of this job. Kessler-Harris described the case as a milestone battle; a confrontation which raised the issue of whether job descriptions should require activitives incompatible with the performance of home and family responsibilities and other vital functions. An agenda including demands for day care centers, improved maternity benefits, comparable worth clauses and work sharing arrangements could emerge if union and labor leaders assumed partial responsibility for the reconceptualization of reasonable job responsibilities to take account of the needs of women workers.

This type of platform diverges from the traditional definition of radicalism, which focuses on the formation and maintenance of a viable labor party or socialist movement. Strict adherence to this definition leaves nineteenthcentury protest movements within the mainstream as relatively few workers supported Marxian Socialism. However, many producers advocated republicanism which drew on the legacy of the American Revolution and the Declaration of Independence. This approach critiqued concentrated wealth and power and justified equal rights and the access of producers to political power, dignity and independence. Artisans embraced the Workingman's Platform and supported Workingmens' Parties in the 1830s while their successors and industrial workers flocked to the banner of the Knights of Labor. Leon Fink (University of North Carolina) described a July 4th address by Terence Powderly to document this linkage. Powderly invoked the principles of the Declaration of Inde- 
pendence to support his vision of a good society based on cooperation and solidarity. Professor Fink's interpretation of the Knights of Labor countered the viewpoint of John Diggins, who has denied that protest movements offered a viable alternative to mainstream American society. To substantiate his judgment Fink cited their distinctive rhetoric and their halls, reading rooms, and picnics which reinforced community and solidarity and spurned destructive competition and individualism. The Knights recruited immigrants, blacks, women and the unskilled and often conformed to its motto, "An injury to one is the concern of all." These practices and values differed from the mainstream and formed an "alternative culture," according to Professor Fink.

However, the "alternative culture" suffered severe setbacks in the 1890 s with the demise of the Knights, the defeat of the Homestead and Pullman Strikers and the decline of the Populists. In the twentieth century the political arena offered less scope for protest activity and the dominant labor unions grew more conservative. The early years of Walter Reuther as president of the UAW provided a partial exception to this trend, according to Nelson Lichtenstein (Catholic University of America). Reuther, especially in the late 1940s, tried to steer the union in some new directions most notably by requesting that the auto companies open their books and reduce auto prices. However, this initiative encountered strong employer resistance and after the 1946 strike he began to refocus negotiations on wages and fringe benefits. This approach produced tangible benefits for the membership and the union but sacrified long-term interests by neglecting corporate investment policies and other vital areas. United Steel Workers of America leaders lacked the initial innovativeness of Reuther and emphasized the safer issues of wage and fringe benefit improvements and cooperation with management to limit imports. This approach produced periodic internal challenges to the conservative centralized leadership climaxed by Edward Sadlowski's race for the president of the union in 1977. Philip Nyden (Loyola University of Chicago) described the campaign as a struggle to democratize the union conducted by a charismatic figure. However, Sadlowski lacked a broad-based support structure and an effective program to revitalize an increasingly troubled industry and work force. Sadlowski won support from blacks, Hispanics, and young workers, but his victory in the basic steel industry failed to assure his elections in an increasingly diversified union.

Several symposium programs provided antecedents and context for understanding their employer offensive of the 1980s. Melvyn Dubofsky cited the Railway Strikes of 1877 as an example of a company and government alliance against the strikers and their allies. "People and Power: The Struggle Continues" featured scenes from the violent labor conflicts of the 1930s with the Little Steel Strike in the spotlight. Another videotape on the current struggle between the coal miners and the United Mine Workers against the A. T. Massey Company and the police brought the role of strike violence up to date. The 
scenes and interviews presented an environment of guns, barbed wire, and strikebreakers devastating the citizens and communities of southern West Virginia and eastern Kentucky.

The call for new directions came from both academics and activists. William Harris suggested studies of the history of children and the role of unemployment as valuable directions for future research. Alice Kessler-Harris recommended a redefinition of the terrain of working class history to include "women's issues" and the non-work environment. Other presenters began formulation of a new agenda to exploit the opportunities of the 1980s mentioned by David Gordon. Everett Kassalow (Carnegie-Mellon University) noted the possibilities presented by a labor force growing at a slower rate and a shift to clerical and governmental employment. Reviving the spirit of the 1930s and redirecting the drive displayed in organized labor's role in the Mondale campaign, could provide a basis for reversing the declining fortunes of the labor movement. Peter Kelly built on this approach in his call for the formation of new coalitions around the issues of a shorter work week, using technology to benefit workers and better health care. Robert Erickson (Carlow College) described corporate investment policy as a crucial issue, in the Pittsburgh area and nationally, and recommended public control in order to revitalize our steel industry and rebuild our deteriorating infrastructure.

The symposium program offered the audience a good brief overview of the current state of U.S. working-class historiography and a glimpse of the new directions being pursued by labor activists. The similarity of perspective did not produce a bland homogeneity but led to a sense of participating in a common search for a better understanding of our past and an agenda for the present and the future. The site of the symposium at a state university in the industrial heartland of the United States enhanced the widespread feeling of the need to relate the scholarship on working-class history to labor activism in order to formulate and implement an agenda for progressive social change to revitalize the region and the nation. 